\title{
Synthesis, Spectral and Thermal Studies, and Crystal Structure of cis-Bis(imidazole)bis(picolinato)copper(II) Dihydrate $\left[\mathrm{Cu}(\mathrm{pic})_{2}(\mathrm{im})_{2}\right] \cdot 2 \mathrm{H}_{2} \mathrm{O}$
}

\author{
Zerrin Heren $^{\mathrm{a}}$, Cem Keser ${ }^{\mathrm{a}}$, C. Cüneyt Ersanlı ${ }^{\mathrm{b}}$, O. Zafer Yeşilel ${ }^{\mathrm{c}}$, and \\ Orhan Büyükgüngör ${ }^{b}$ \\ ${ }^{a}$ Ondokuz Mayis University, Faculty of Arts and Sciences, Department of Chemistry, \\ TR-55139, Kurupelit, Samsun, Turkey \\ b Ondokuz Mayis University, Faculty of Arts and Sciences, Department of Physics, \\ TR-55139, Kurupelit, Samsun, Turkey \\ ${ }^{\mathrm{c}}$ Eskişehir Osmangazi University, Faculty of Arts and Sciences, Department of Chemistry, \\ TR-26480, Eskişehir, Turkey
}

Reprint requests to Dr. Z. Heren. E-mail: zheren@omu.edu.tr

Z. Naturforsch. 61b, 1072 - 1078 (2006); received February 1, 2006

The mixed-ligand picolinato (pic) complex of $\mathrm{Cu}(\mathrm{II})$ with imidazole (im), $\left[\mathrm{Cu}(\mathrm{pic})_{2}(\mathrm{im})_{2}\right] \cdot 2 \mathrm{H}_{2} \mathrm{O}$, was synthesized and characterized by elemental analysis, magnetic susceptibility, spectral methods (UV/vis and FT-IR), simultaneous TG, DTA techniques, mass spectroscopy, and X-ray diffraction. The complex crystallizes in the monoclinic space group $C c$ with the following unit cell parameters: $a=16.381(1), b=9.556(1), c=5.177(1) \AA, \beta=119.074(5)^{\circ}, Z=4$. In the octahedral complex, the picolinato ligands are coordinated to the copper(II) ion as bidentate $N, O$-donors forming chelate rings. The imidazole ligands are $N$-coordinated at $c i s$ positions. The thermal decomposition pathway of the complex has been studied by the help of thermal analyses data (TG and DTA) and of the mass spectroscopic fragmentation pattern. The volatile products observed in the thermal decomposition process were also observed in the mass spectrometer ionisation process, except for the molecular peak, and it was concluded that the ionisation and thermal decomposition pathways of the complex resemble each other.

Key words: Picolinic Acid, Imidazole, Copper(II) Complex, Thermal Decomposition

\section{Introduction}

Pyridinecarboxylic acids and their derivatives are present in many natural products. They are also of special interest to medicinal chemists because of the wide variety of physiological properties displayed by the natural and also many synthetic derivatives [1]. For example, picolinic acid is one of the metabolites of tryptophan [2]. Zinc(II) pyridine 2-carboxylate has healing effects against Herpes Simplex virus [3]. The picolinic acid (pyridine 2-carboxylic acid, pic) is the body's prime natural chelator. The picolinato ligand is able to chelate with metal ions and can display widely varying coordination behaviour function as a multidentate ligand. It is the most efficient chelator for metal cations such as chromium, zinc, manganese, copper, iron and molybdenum when they are in the body. One of the ways to understand chemistry and properties of the picolinic acid is to study the structures of its metal complexes [4-7]. Imidazole is a very important model molecule since the imidazole ring occurs in a series of biological molecules such as in histidine, in Vitamin $B_{12}$ and biotin as well as in many chemotherapic agents [8].

In this paper, we report the preparation, characterization by FT-IR and UV/vis measurements, thermal analyses data (TG and DTA), mass spectroscopic fragmentation pattern, and crystal structure of the cis-bis(imidazole)bis(picolinato)copper(II) dihydrate complex.

\section{Results and Discussion}

IR spectra

In the IR spectrum of the complex the broad band at $3435 \mathrm{~cm}^{-1}$ corresponds to the vibration of water molecules. The bands that appear at 3108 and $2992 \mathrm{~cm}^{-1}$ are due the absorption bands of the $\mathrm{NH}$ moiety of imidazole. In the IR spectrum of the 
free picolinic acid there is a strong absorption band at $1730 \mathrm{~cm}^{-1}$ for the $\mathrm{COOH}$ group. In the IR spectrum of the $\mathrm{Cu}(\mathrm{II})$ complex this absorption band is absent and the band due to the asymmetric stretch $v_{\text {asym }}$ $\left(\mathrm{COO}^{-}\right)$and symmetric stretch $v_{\text {sym }}\left(\mathrm{COO}^{-}\right)$are observed at 1643 and $1353 \mathrm{~cm}^{-1}$, respectively. The difference $v_{\text {asym }}\left(\mathrm{COO}^{-}\right)$and $v_{\text {sym }}\left(\mathrm{COO}^{-}\right)$being 290 can be taken as a proof of unidentate coordination of the carboxylate group to the central atom [9]. This is in good agreement with the results obtained from $\mathrm{X}$-ray diffraction measurements. In the complex, the band at $1595 \mathrm{~cm}^{-1}$ can be attributed to the $(-\mathrm{C}=\mathrm{N}-)$ stretching vibration. The $\mathrm{M}-\mathrm{O}$ stretching vibration of the complex was observed at $455 \mathrm{~cm}^{-1}$.

\section{UV/vis spectra and magnetic susceptibility}

The electronic spectrum of the $\left[\mathrm{Cu}(\text { pic })_{2-}\right.$ (im) $)_{2} \cdot 2 \mathrm{H}_{2} \mathrm{O}$ in water exhibit a broad absorption band at $642 \mathrm{~nm}\left(\varepsilon=41.0 \mathrm{Lmol}^{-1} \mathrm{~cm}^{-1}\right)$ due to the $d$-d transition and a shoulder at $590 \mathrm{~nm}$ ( $\varepsilon=25.0 \mathrm{Lmol}^{-1} \mathrm{~cm}^{-1}$ ) assigned to the Jahn-Teller effect. This $\lambda_{\max }$ value was assigned to the ${ }^{2} \mathrm{E}_{\mathrm{g}} \rightarrow{ }^{2} \mathrm{~T}_{2 \mathrm{~g}}$ transition. The $\Delta_{\mathrm{o}}$ value for the complex was calculated as $15,576 \mathrm{~cm}^{-1}$, since there is only one transition for $d^{9}$ complexes [10]. The absorption bands below $300 \mathrm{~nm}$ are due to intra-ligand transitions.

The magnetic susceptibility value of the complex is 1.67 BM corresponding to one unpaired electron.

\section{Thermal analysis}

Thermal analyses curves of the complex (TG and DTA) are given in Fig. 1. The thermal behaviour of the complex was followed up to $600{ }^{\circ} \mathrm{C}$ in a static air atmosphere. The first stage of the thermal decompo-

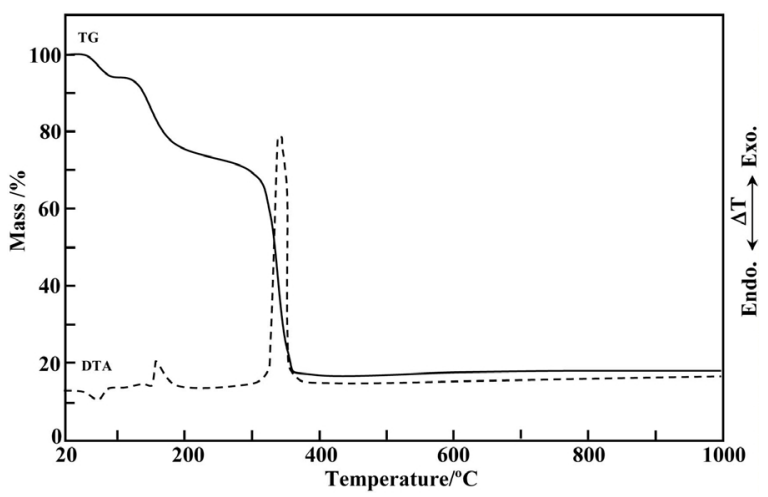

Fig. 1. The TG and DTA curves of the $\left[\mathrm{Cu}(\mathrm{pic})_{2}-\right.$ (im) $\left.)_{2}\right] \cdot 2 \mathrm{H}_{2} \mathrm{O}$ complex. sition starts at $65{ }^{\circ} \mathrm{C}$ with the release of two crystal water molecules associated with an endothermic effect $\left(\mathrm{DTA}_{\max } 78{ }^{\circ} \mathrm{C}\right.$; found $7.52 \%$; calcd. $7.50 \%$ ). The second stage in the $135-302{ }^{\circ} \mathrm{C}$ temperature range corresponds to the exothermic elimination of two moles of imidazole ligands $\left(\mathrm{DTA}_{\max } 161{ }^{\circ} \mathrm{C}\right)$. The experimental mass loss of $27.79 \%$ agrees well with the calculated mass loss of $28.37 \%$. The decomposition of the two picolinato ligands occurs in the third stage between 305 and $460{ }^{\circ} \mathrm{C}$ with one violently exothermic DTA peak at $347{ }^{\circ} \mathrm{C}$. The final decomposition product $\mathrm{CuO}$, was identified by IR spectroscopy (found $81.67 \%$; calcd. $83.43 \%$ ).

\section{Analysis of the mass spectrum}

The mass spectrum of any substance mainly reveals the most delicate and fragile points present in the structure of a molecule. It was assumed that the thermal process somewhat resembles the ionisation process $[11,12]$. For this purposes, the mass spectrum of $\left[\mathrm{Cu}(\mathrm{pic})_{2}(\mathrm{im})_{2}\right] \cdot 2 \mathrm{H}_{2} \mathrm{O}$ complex was recorded to establish a relation between the thermal and ionisation process to formulate more appropriately the thermal decomposition pathway. The mass spectrum was recorded by the FAB technique. It is not very complicated and only a few major peaks appeared in significant quantities. No molecular ion peak was observed. Absence of the molecular peak may indicate that almost all of the molecular ion is decomposed in the ionization process. The peak observed at $\mathrm{m} / z=445$ possibly corresponds to the $\left[\mathrm{Cu}(\mathrm{pic})_{2}(\mathrm{im})_{2}\right]$ molecule produced by the loss of two moles of water molecules in the ionisation process. The peaks observed at $\mathrm{m} / \mathrm{z}=$ 375 and 307 values may correspond to the species $\left[\mathrm{Cu}(\text { pic })_{2}(\mathrm{im})\right]$ and $\left[\mathrm{Cu}(\text { pic })_{2}\right]$, respectively. Formation of these fragments in the thermal process may also be proved by the thermal analysis data, since $\left[\mathrm{Cu}(\mathrm{pic})_{2}\right]$ was observed after the loss of water molecules at $65-$ $128{ }^{\circ} \mathrm{C}$ (found 7.52\%; calcd. 7.50\%) and of two moles of imidazole ligands at $135-302{ }^{\circ} \mathrm{C}$ (found $27.79 \%$; calcd. $28.37 \%$ ). An intermediate compound is formed from $\left[\mathrm{Cu}(\text { pic })_{2}(\mathrm{im})\right]$ by the release of one mole $\mathrm{CO}_{2}$ as observed in the mass spectrum at $m / z=331$. This may confirm that a picolinato ligand is thermally decomposed by the release of $\mathrm{CO}_{2}$. The observed ionisation products resemble the products predicted by the thermal analysis results. The decomposition products observed in the ionisation process are given in Fig. 2. 


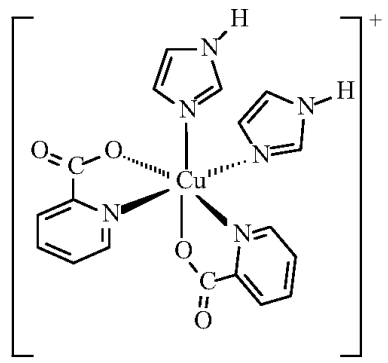

$\mathrm{m} / \mathrm{z}=445$
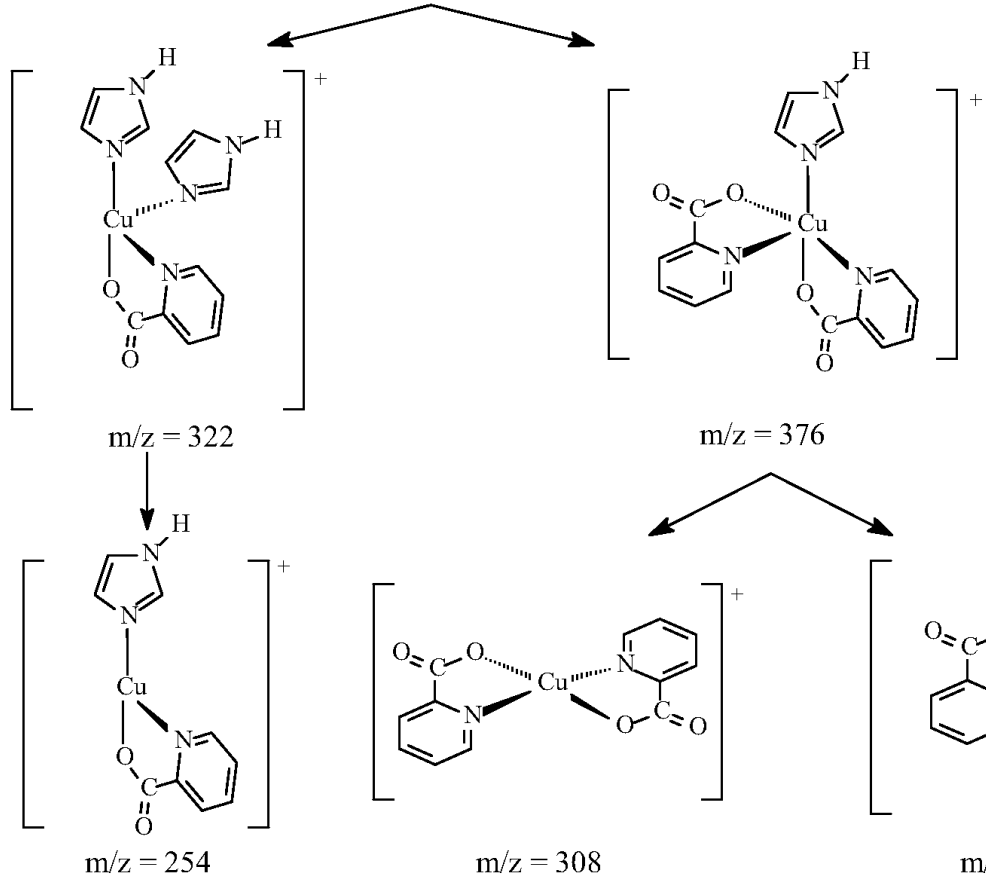

$\mathrm{m} / \mathrm{z}=254$

$\mathrm{m} / \mathrm{z}=308$

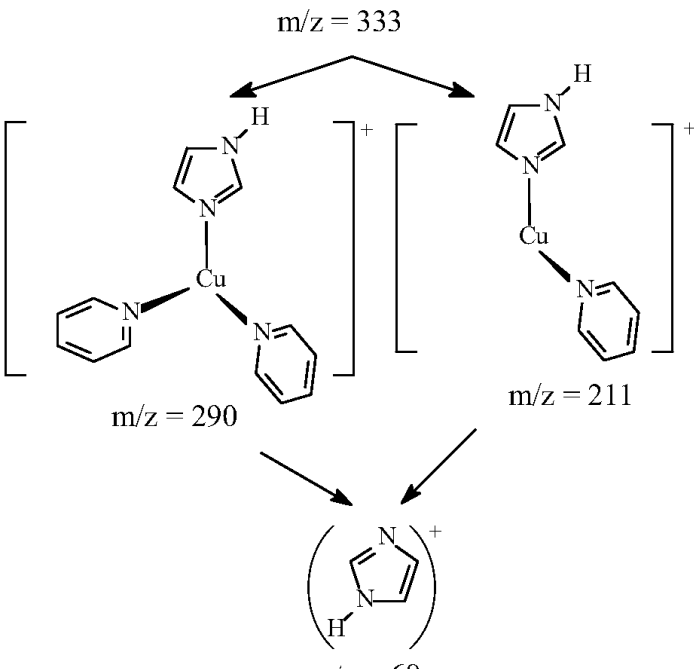

Fig. 2. Mass spectral fragmentation pattern of the $\left[\mathrm{Cu}(\mathrm{pic})_{2}(\mathrm{im})_{2}\right] \cdot 2 \mathrm{H}_{2} \mathrm{O}$ complex. 
Table 1. Crystal data and structure refinement parameters for $\left[\mathrm{Cu}(\text { pic })_{2}(\mathrm{im})_{2}\right] \cdot 2 \mathrm{H}_{2} \mathrm{O}$.

\begin{tabular}{|c|c|}
\hline Formula & $\mathrm{C}_{18} \mathrm{H}_{20} \mathrm{~N}_{6} \mathrm{O}_{6} \mathrm{Cu}$ \\
\hline Colour & blue \\
\hline Molecular weight & 479.94 \\
\hline Temperature (K) & 296 \\
\hline Wavelength $(\AA)$ & $0.71073 \mathrm{Mo}-\mathrm{K}_{\alpha}$ \\
\hline Crystal system & monoclinic \\
\hline Space group & Cc \\
\hline \multicolumn{2}{|l|}{ Unit cell dimensions } \\
\hline$a(\AA)$ & $16.381(1)$ \\
\hline$b(\AA)$ & $9.556(1)$ \\
\hline$c(\AA)$ & $15.177(1)$ \\
\hline$\beta\left({ }^{\circ}\right)$ & $119.074(5)$ \\
\hline Volume $\left(\AA^{3}\right)$ & $2076.3(3)$ \\
\hline$Z$ & 4 \\
\hline$D_{\text {calc }}\left(\mathrm{Mgm}^{-3}\right)$ & 1.535 \\
\hline$\mu\left(\mathrm{mm}^{-1}\right)$ & 1.100 \\
\hline Crystal size $\left(\mathrm{mm}^{-3}\right)$ & $0.42 \times 0.31 \times 0.22$ \\
\hline$\Theta$ Range for data collection & $1.5-26.9^{\circ}$ \\
\hline Flack’s $x$ parameter [21] & $0.02(2)$ \\
\hline \multicolumn{2}{|l|}{ Index ranges } \\
\hline$h$ & $-21 \rightarrow 21$ \\
\hline$k$ & $-12 \rightarrow 12$ \\
\hline$l$ & $-19 \rightarrow 17$ \\
\hline Reflections collected & 6614 \\
\hline Independent reflections & $2454\left(R_{\mathrm{int}}=0.002\right)$ \\
\hline Reflections observed $(>2 \sigma)$ & 4249 \\
\hline Absorption correction & integration \\
\hline Max. and min. Transmission & 0.767 and 0.875 \\
\hline Refinement method & $F^{2}$ \\
\hline$w$ & $\begin{array}{l}1 /\left[2 \sigma\left(F_{\mathrm{o}}^{2}\right)+(0.1041 P)^{2}\right] \\
\text { where } P=\left(F_{\mathrm{o}}^{2}+2 F_{\mathrm{c}}^{2}\right) / 3\end{array}$ \\
\hline Goodness-of-fit on $F^{2}$ & 0.91 \\
\hline $\begin{array}{l}\text { Final } R \text { indices }\left[F^{2}>2 \sigma\left(F^{2}\right)\right] \\
w R\left(F^{2}\right)\end{array}$ & $\begin{array}{l}R_{1}=0.057, R_{1}(\text { all data })=0.092 \\
w R_{2}=0.133, w R_{2}(\text { all data })=0.168\end{array}$ \\
\hline $\begin{array}{l}\text { Largest difference peak } \\
\text { and hole }\left(\mathrm{e} \AA^{-3}\right)\end{array}$ & -0.76 to 0.91 \\
\hline CCDC deposition no. & CCDC 286619 \\
\hline
\end{tabular}

Table 2. Selected bond lengths $(\AA)$ and bond angles $\left({ }^{\circ}\right)$ for $\left[\mathrm{Cu}(\text { pic })_{2}(\mathrm{im})_{2}\right] \cdot 2 \mathrm{H}_{2} \mathrm{O}$.

\begin{tabular}{llll}
\hline $\mathrm{Cu}(1)-\mathrm{N}(1)$ & $2.022(4)$ & $\mathrm{Cu}(1)-\mathrm{O}(1)$ & $2.320(4)$ \\
$\mathrm{Cu}(1)-\mathrm{N}(3)$ & $1.988(6)$ & $\mathrm{Cu}(1)-\mathrm{O}(2)$ & $2.257(4)$ \\
$\mathrm{Cu}(1)-\mathrm{N}(4)$ & $2.095(4)$ & $\mathrm{C}(9)-\mathrm{O}(1)$ & $1.279(9)$ \\
$\mathrm{Cu}(1)-\mathrm{N}(5)$ & $1.999(9)$ & $\mathrm{C}(9)-\mathrm{O}(3)$ & $1.241(7)$ \\
& & $\mathrm{C}(15)-\mathrm{O}(2)$ & $1.234(7)$ \\
& & $\mathrm{C}(15)-\mathrm{O}(4)$ & $1.248(7)$ \\
$\mathrm{N}(1)-\mathrm{Cu}(1)-\mathrm{N}(4)$ & $172.5(2)$ & $\mathrm{N}(5)-\mathrm{Cu}(1)-\mathrm{N}(4)$ & $88.9(3)$ \\
$\mathrm{N}(3)-\mathrm{Cu}(1)-\mathrm{N}(1)$ & $88.7(3)$ & $\mathrm{N}(3)-\mathrm{Cu}(1)-\mathrm{O}(2)$ & $93.8(2)$ \\
$\mathrm{N}(3)-\mathrm{Cu}(1)-\mathrm{N}(4)$ & $91.2(3)$ & $\mathrm{N}(5)-\mathrm{Cu}(1)-\mathrm{O}(2)$ & $89.7(3)$ \\
$\mathrm{N}(3)-\mathrm{Cu}(1)-\mathrm{N}(5)$ & $176.3(3)$ & $\mathrm{N}(4)-\mathrm{Cu}(1)-\mathrm{O}(2)$ & $76.4(2)$ \\
$\mathrm{N}(5)-\mathrm{Cu}(1)-\mathrm{N}(1)$ & $91.7(3)$ & $\mathrm{N}(4)-\mathrm{Cu}(1)-\mathrm{O}(1)$ & $91.5(2)$ \\
\hline
\end{tabular}

\section{Crystallography}

The structure of the title complex, $\left[\mathrm{Cu}(\text { pic })_{2}-\right.$ (im) $\left.)_{2}\right] \cdot 2 \mathrm{H}_{2} \mathrm{O}$, is shown in Fig. 3 and the crystallo-
Table 3. Hydrogen bonding geometry $\left(\AA{ }^{\circ}{ }^{\circ}\right)$.

\begin{tabular}{|c|c|c|c|c|}
\hline$\overline{\mathrm{D}-\mathrm{H} \cdots \mathrm{A}}$ & D-H & $\mathrm{H} \cdots \mathrm{A}$ & $\mathrm{D} \cdots \mathrm{A}$ & $\overline{D-H} \cdots A$ \\
\hline$\overline{\mathrm{O}} 5-\mathrm{H} 5 \mathrm{~A} \cdots \mathrm{O} 1$ & $0.920(10)$ & $1.984(14)$ & $2.876(7)$ & $163.1(6)$ \\
\hline O6-H6B $\cdots$ O5 & $0.91(5)$ & $2.41(5)$ & $2.972(12)$ & $119(5)$ \\
\hline $\mathrm{C} 10-\mathrm{H} 10 \cdots \mathrm{O} 1$ & 0.93 & 2.60 & $3.197(8)$ & 122.9 \\
\hline $\mathrm{N} 2-\mathrm{H} 2 \mathrm{~N} \cdots \mathrm{O} 6^{\mathrm{i}}$ & 0.86 & 1.99 & $2.833(8)$ & 164.9 \\
\hline O5-H5B $\cdots N 6^{\mathrm{ii}}$ & $0.923(10)$ & $2.27(5)$ & $2.797(9)$ & $116(4)$ \\
\hline O6-H6A $\cdots$ O $4^{\text {iii }}$ & $0.915(10)$ & $2.106(16)$ & $2.792(6)$ & $130.9(15)$ \\
\hline $\mathrm{N} 6-\mathrm{H} 6 \mathrm{~N} \cdots \mathrm{O} 5^{\mathrm{iv}}$ & 0.86 & 1.98 & $2.797(9)$ & 158.1 \\
\hline $\mathrm{C} 3-\mathrm{H} 3 \cdots \mathrm{O} 4^{\mathrm{v}}$ & 0.93 & 2.49 & $3.200(8)$ & 133.3 \\
\hline
\end{tabular}

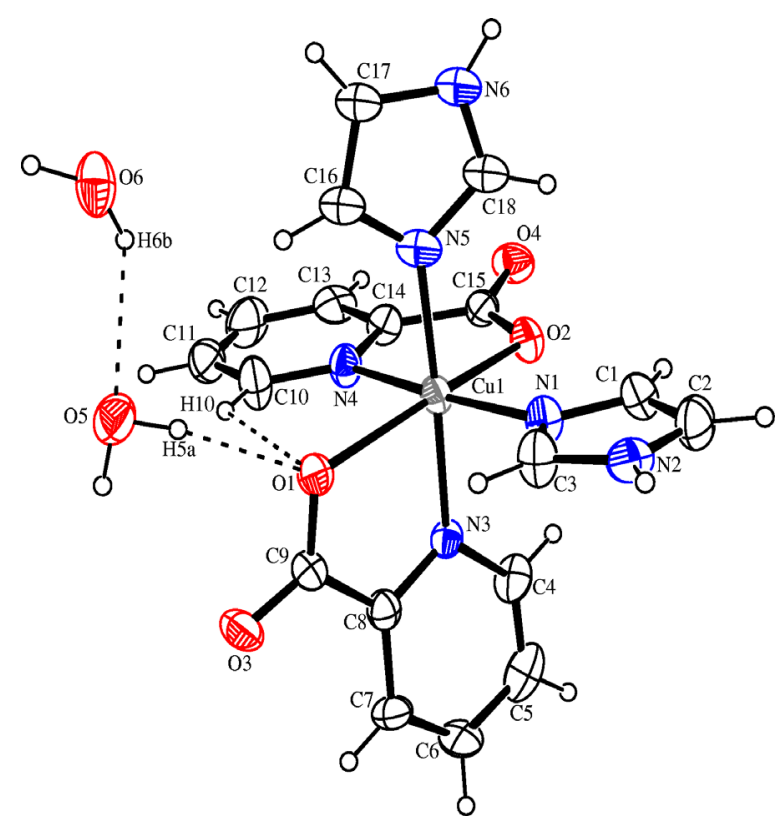

Fig. 3. A view of the copper coordination, with the atom labeling scheme. Displacement ellipsoids are drawn at the $50 \%$ probability level.

graphic data are summarized in Table 1. Tables 2 and 3 list bond lengths and angles and hydrogen-bonding geometries. The $\mathrm{Cu}(\mathrm{II})$ ion has a slightly distorted octahedral coordination geometry comprised of the two atoms $\mathrm{N} 3$ and $\mathrm{N} 4$, two carboxylate $\mathrm{O}$ atoms from deprotonated bidentate picolinate ligands, and two tertiary $\mathrm{N}$ atoms from imidazole molecules. Atoms N3 and $\mathrm{O} 1$ and $\mathrm{N} 4$ and $\mathrm{O} 2$ are bonded to $\mathrm{Cu} 1$ to form two five-membered chelate ring $[\mathrm{N} 3-\mathrm{Cu} 1=1.988(6)$ and $\mathrm{O} 1-\mathrm{Cu} 1=2.320(4) \AA$; $\mathrm{N} 4-\mathrm{Cu} 1=2.095(4)$ and $\mathrm{O} 2-\mathrm{Cu} 1=2.257(4) \AA]$. The imidazole atom $\mathrm{N} 1$ $[\mathrm{Cu} 1-\mathrm{N} 1=2.022(4) \AA]$ is in an equatorial position and the imidazole atom N5 [Cu1-N5 = 1.999(9) $\AA$ ] in an apical position of the $\mathrm{Cu}(\mathrm{II})$ coordination octahedron. 


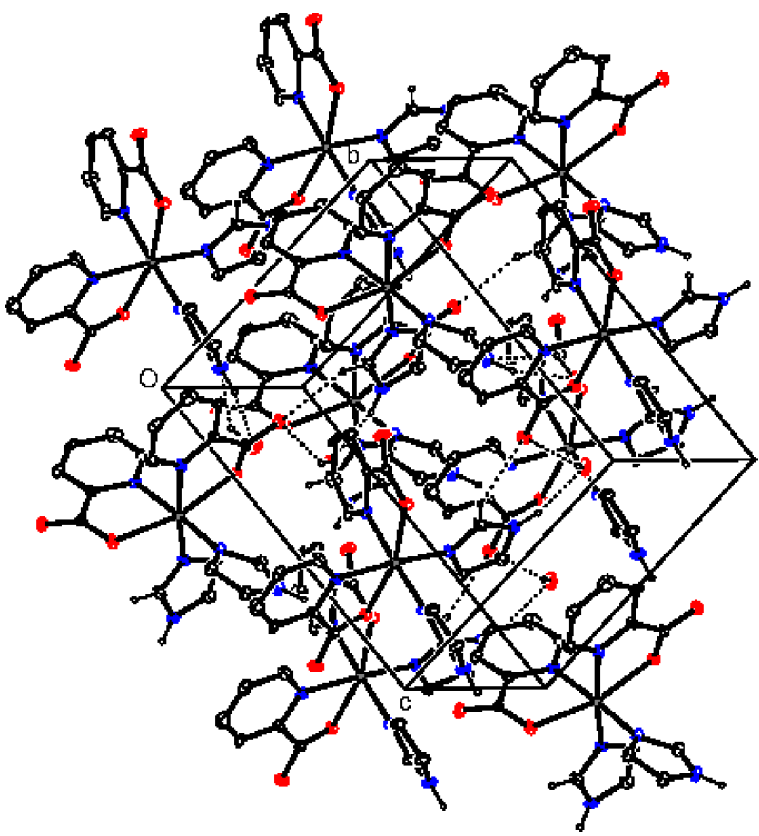

Fig. 4. The packing of the $\left[\mathrm{Cu}(\text { pic })_{2}(\mathrm{im})_{2}\right] \cdot 2 \mathrm{H}_{2} \mathrm{O}$ complex with the unit cell.

The C-O bond lengths are in the range 1.234(7)1.279(9) $\AA$, which is comparable with those in similar $\mathrm{Cu}(\mathrm{II})$ complexes [13]. However, in the Co(II) [13], $\mathrm{Ni}(\mathrm{II})$ [14] and $\mathrm{Mg}(\mathrm{II})$ [15] complexes, the carboxylate group is asymmetric $[\mathrm{C}-\mathrm{O}=1.223(3)-1.278(2)$, $1.248(2)-1.253(2)$ and $1.243(2)-1.262(2) \AA$, respectively].

As shown in Table 1, the lengths of the $\mathrm{Cu}-\mathrm{N}$ bonds $[1.988(6)-2.095(4) \AA]$ are normal, and these distances are similar to other values reported in the literature [16]. The coordination of copper(II) clearly shows the geometrical pattern typical for the JahnTeller effect. The Cu1-N3 and Cu1-N4 distances are shorter than the $\mathrm{Cu} 1-\mathrm{O} 1$ and $\mathrm{Cu} 1-\mathrm{O} 2$ distances, and this results in the formation of an octahedral geometry elongated along the $\mathrm{N}$ atoms. The JahnTeller effect is also observed in the electronic spectra. This effect is common for analogous metal complexes, such as [17] [Cu1-N3 = 2.007(3) and $\mathrm{Cu} 1-\mathrm{O} 1=2.383(3) \AA]$ and $[18][\mathrm{Cu} 1-\mathrm{N} 2=2.006(2)$ and $\mathrm{Cu} 1-\mathrm{O} 3=2.390(2) \AA$ ] .

The title compound contains two pyridine rings and two imidazole rings. For simplicity, the four rings will be called A, B, C and D, corresponding to N3/C4-C8, N4/C10-C14, N1/N2/C1-C3 and N5/N6/C16-C18, respectively. The dihedral angles between the planes of the rings are $\mathrm{A} / \mathrm{C}=85.36(31), \mathrm{A} / \mathrm{D}=23.99(44)$,

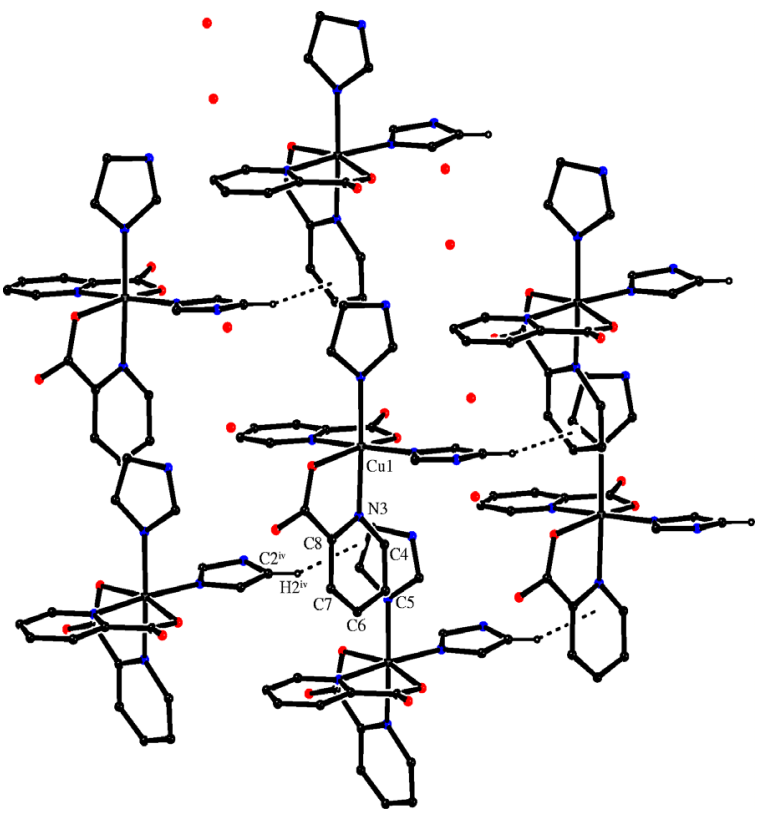

Fig. 5. The $\mathrm{C}-\mathrm{H} \cdots \pi$ interactions of the molecules.

$\mathrm{B} / \mathrm{C}=2.96(40)$ and $\mathrm{B} / \mathrm{D}=89.17(36)^{\circ}$. The two imidazole rings are individually planar, with r.m.s. deviations of 0.0095 and $0.0004 \AA$, and the maximum deviations from these planes are $-0.0086(62) \AA$ for atom C3 and 0.0005(5) $\AA$ for atom C18. These planes are approximately perpendicular, with a dihedral angle of $86.46(41)^{\circ}$, in agreement with those previously reported for other imidazole and picolinate ligands containing $\mathrm{Cu}(\mathrm{II})$ complexes $[19,20]$. The crystal packing of the title complex is formed by intermolecular N-H... O, O-H... O, O-H... N, and C-H. . O hydrogen bondings (Table 3, Fig. 4) and $\pi$-ring interaction (Fig. 5). For the $\mathrm{C} 2-\mathrm{H} 2 \ldots \mathrm{CgA}$ (CgA with symmetry code: $x+1 / 2,1 / 2-y, 1 / 2+z$ is the centroid of $\mathrm{N} 3 / \mathrm{C} 4-\mathrm{C} 8) \pi$-ring contact, the distance between atom $\mathrm{H} 2$ and the centre of ring $\mathrm{A}(\mathrm{CgA})$ is $2.92 \AA$, and the $\mathrm{C} 2-\mathrm{H} 2$. . CgA angle is $132.7^{\circ}$.

\section{Experimental Section}

Materials and measurements

All chemicals used were analytical reagent grade products. Imidazole was obtained from Merck. Picolinic acid was purchased from ACROS Organics.

The magnetic susceptibility measurement at r.t. was performed using a Sherwood Scientific MXI model Gouy magnetic balance. The UV/vis spectrum was obtained for the aqueous solution of the complex $\left(10^{-3} \mathrm{M}\right)$ with a Unicam UV2 spectrometer in the range $900-190 \mathrm{~nm}$. The IR 
spectrum was recorded in the $4000-400 \mathrm{~cm}^{-1}$ region with a Mattson 1000 FT-IR spectrometer using $\mathrm{KBr}$ pellets. A TG8110 thermal analyzer was used to record simultaneous TG and DTA curves in static air atmosphere at a heating rate of $10 \mathrm{Kmin}^{-1}$ in the temperature range $20-1000{ }^{\circ} \mathrm{C}$ using platinum crucibles. Highly sintered $\alpha-\mathrm{Al}_{2} \mathrm{O}_{3}$ was used as a reference and the DTG sensitivity was $0.05 \mathrm{mg} \mathrm{s}^{-1}$. The elemental and mass spectroscopic analysis was carried out at the TÜBİTAK Marmara Research Centre. Mass spectroscopic analysis was performed on a AGILENT 1100 MSD mass spectrometer.

\section{$X$-ray structure determination}

Data collection was performed on a STOE IPDS-II image plate detector using Mo- $\mathrm{K}_{\alpha}$ radiation $(\lambda=0.71073 \AA)$. Intensity data were collected in the $\theta$ range $1.5-26.9^{\circ}$ at 296 K. Details of crystal structures are given in Table 1. Data collection and cell refinement: STOE X-AREA [22]. Data reduction: STOE X-RED32 [22]. The structure was solved by direct methods using SHELXS-97 [23]. Anisotropic displacement parameters were applied to nonhydrogen atoms in a full-matrix least-squares refinement based on $F^{2}$ using SHELXL-97 [23]. All hydrogen atoms except those bound to $\mathrm{O} 5$ and $\mathrm{O} 6$ were placed in calculated positions and refined using a riding model, with $\mathrm{C}-\mathrm{H}$ distances of 0.93 (aromatic), N-H distances of $0.86 \AA$ and with $U_{\text {iso }}(\mathrm{H})=1.2 U_{\text {eq }}(\mathrm{C}, \mathrm{N})$. Molecular drawings were obtained using ORTEP-III [24]. Software used to prepare material for publication: WinGX [25].
Preparation of the $\left[\mathrm{Cu}(\text { pic })_{2}(\mathrm{im})_{2}\right] \cdot 2 \mathrm{H}_{2} \mathrm{O}$

The $\left[\mathrm{Cu}(\text { pic })_{2}\right] \cdot 2 \mathrm{H}_{2} \mathrm{O}$ complex was prepared by the method reported earlier [26]. A solution of im $(0.27 \mathrm{~g}$, $4 \mathrm{mmol})$ in ethanol $(10 \mathrm{ml})$ was added dropwise with stirring to a solution of $\left[\mathrm{Cu}(\text { pic })_{2}\right] \cdot 2 \mathrm{H}_{2} \mathrm{O}(0.69 \mathrm{~g}, 2 \mathrm{mmol})$ in distilled water $(20 \mathrm{ml})$. The solution was heated to $60{ }^{\circ} \mathrm{C}$ in a temperature-controlled bath and stirred for $6 \mathrm{~h}$. The reaction mixture was then cooled to r.t. The blue crystals formed were filtered and washed with $10 \mathrm{ml}$ of cold distilled water and ethanol and dried in air. UV/vis $\left(\mathrm{H}_{2} \mathrm{O}\right)$ : $\lambda_{\max }(\lg \varepsilon)=642 \mathrm{~nm}(3.71) .-\operatorname{IR}(\mathrm{KBr}): \tilde{v}=3435 \mathrm{~cm}^{-1}$ (OH), 1643, 1353, 1595, 455. - MS (ES, $35 \mathrm{eV}): m / z(\%)=$ $445\left[\mathrm{Cu}(\text { pic })_{2}(\mathrm{im})_{2}\right]^{+}, 375$ (68) $\left[\mathrm{Cu}(\text { pic })_{2}(\mathrm{im})_{2}-(\mathrm{im})\right]^{+}$. $\mathrm{C}_{18} \mathrm{H}_{20} \mathrm{~N}_{6} \mathrm{O}_{6} \mathrm{Cu}$ (479.9): calcd. C 45.05, H 4.17, N 17.52; found $\mathrm{C} 45.01, \mathrm{H}$ 4.22, N 17.28.

\section{Supplementary Data}

Crystallographic data (excluding structure factors) have been deposited with the Cambridge Crystallographic Data Centre as the supplementary publication No. CCDC 286619. Copies of the data can be obtained, free of charge, on application to CCDC, 12 Union Road, Cambridge CB2 1EZ, UK (fax: +44-1223-336033 or e-mail: deposit@ccdc.cam.ac.uk).

\section{Acknowledgements}

The authors wish to acknowledge the Faculty of Arts and Sciences, Ondokuz Mayis University, Turkey, for the use of the STOE IPDS-II diffractometer (purchased under grant F.279 of the University Research Fund).
[1] K. A. Idriss, M. S. Saleh, H. Sedaira, M. M. Sleim, E. Y. Hashem, Monatsh. Chem. 122, 507 (1991).

[2] R. Song, K. M. Kim, Y. S. Sohn, Inorg. Chim. Acta 292, 238 (1999).

[3] T. L. Varadinova, P. R. Bontehev, C. K. Nachev, S. A. Shiskov, J. Chemother. 5, 3 (1993).

[4] N.E. Chakov, R. A. Collins, J. B. Vincent, Polyhedron 22, 2891 (1999).

[5] R. March, W. Clegg, R.A. Coxall, L. CucurullSánchez, L. Lezama, T. Rojo, P. González-Duarte, Inorg. Chim. Acta 353, 129 (2003).

[6] S.L. Jain, P. Bhattacharya, H. L. Milton, A.M. Z. Slawin, J. D. Woollins, Inorg. Chem. Comm. 7, 423 (2004).

[7] S. Basu, S.-M. Peng, G.-H. Lee, S. Bhattacharya, Polyhedron 24, 157 (2005).

[8] R. M. Achelson, Introduction to the Chemistry of Heterocyclic Compounds, Wiley, New York (1986).

[9] K. Nakamato, Infrared and Raman Spectra of Inorganic and Coordination Compounds, p. 232, Wiley \& Sons, New York (1986).

[10] D. Sutton, Electrostatic Energy Level Diagrams and the
Spectra of Octahedral Complexes. In Electronic spectra of Transition Metal Complexes, p. 115, McGrawHill, London (1968).

[11] M. Rehakova, K. Jesenak, S. Nagyova, R. Kubinec, S. Cuvanova, V. S. Fajnor, J. Therm. Anal. Cal. 76, 139 (2004).

[12] D. Czakis-Sulikowska, A. Czylkowska, J. Therm. Anal. Cal. 76, 543 (2004).

[13] H. Icbudak, H. Ölmez, O. Z. Yesilel, F. Arslan, P. Naumov, G. Jovanovski, A. R. Ibrahim, A. Usman, H. K. Fun, S. Chantrapromma, S. W. Ng, J. Mol. Struct. 657, 255 (2003).

[14] I. Ucar, A. Bulut, O.Z. Yesilel, H. Ölmez, O. Büyükgüngör, Acta Crystallogr. C60, m563 (2004).

[15] I. Mutikainen, R. Hamalatainen, M. Klinga, O. Orama, U. Turpeinen, Acta Crystallogr. C52, 2480 (1996).

[16] H.-Y. Wang, S.-J. Liu, R.-J. Wang, C.-C. Su, Acta Crystallogr. C59, m512 (2003).

[17] C.-S. Gu, S. Gao, L.-H. Huo, H. Zhao, J.-G. Zhao, Acta Crystallogr. E60, m1852 (2004).

[18] M. Bhar, M. Chaudhury, E. R. T. Tiekink, Acta Crystallogr. E57, m305 (2001). 
[19] J. G. Díaz, J. Kožíǐsek, M. Fronc, A. Gatial, I. Svoboda, V. Langer, Acta Crystallogr. C61, m180 (2005).

[20] L. Wang, D.-H. Zhou, J.-P. Zhang, Acta Crystallogr. E61, m958 (2005).

[21] H. D. Flack, Acta Crystallogr. A39, 876 (1983).

[22] Stoe \& Cie, X-AREA (version 1.18) and X-RED32 (version 1.04). Stoe \& Cie, Darmstadt, Germany (2002).

[23] G. M. Sheldrick, SHELXS-97 and SHELXL-97. Program for Crystal Structure Refinement, University of Göttingen, Germany (1997).
[24] M. N. Burnett, C. K. Johnson, ORTEP-III. Report ORNL-6895. OAK Ridge National Laboratory, Tennessee, U.S.A. (1996).

[25] L. J. Farrugia, WinGX Suite for Single Crystal Small Molecule Crystallography, J. Appl. Crystallogr. 32, 837 (1999).

[26] R. Faure, H. Loiseleur, G. Thomas-David, Acta Crystallogr. B29, 1890 (1973). 